\title{
Ammonia Transport in Free-living and Symbiotic Rhizobium sp. ANU289
}

\author{
By SUSAN M. HOWITT, * MICHAEL K. UDVARDI, DAVID A. DAY AND \\ PETER M. GRESSHOFF \\ Botany Department, Australian National University, PO Box 4, Canberra 2601, Australia
}

(Received 20 April 1985; revised 12 September 1985)

$\left[{ }^{14} \mathrm{C}\right]$ Methylamine uptake by free-living Rhizobium sp. ANU289 had Michaelis-Menten kinetics (apparent $\left.K_{\mathrm{m}} 6.6 \mu \mathrm{M}\right)$. Uptake was competitively inhibited by ammonia $\left(K_{\mathrm{i}} 0.4 \mu \mathrm{M}\right)$ and was dependent on an energized membrane. Uptake by bacteria had an optimum at $\mathrm{pH} 7 \cdot 0$. Methylamine uptake by bacteroids from siratro root nodules was much slower than that by freeliving bacteria at $\mathrm{pH} 7.0$ but increased exponentially with the $\mathrm{pH}$ of the medium. Uptake by bacteroids did not show saturation kinetics and was insensitive to the presence of ammonia or uncouplers. These results suggest that free-living bacteria (grown under conditions where ammonia is limiting) have an active transport mechanism for the uptake of ammonium ions; this carrier is not operative in the symbiotic state, where passive diffusion of ammonia occurs. In the free-living state, the ammonium carrier is under genetic control, being repressed by growth on high concentrations of ammonia. Derepression occurs under conditions of nitrogen starvation.

\section{INTRODUCTION}

Rhizobium spp. fix $\mathrm{N}_{2}$ in symbiotic association with legumes. The bacteria induce the formation of nodules on legume roots and differentiate inside the nodule to form bacteroids, which can convert atmospheric $\mathrm{N}_{2}$ to ammonia. The ammonia produced in the bacteroids, however, is assimilated by plant enzymes in the plant cytosol. Thus, the mechanism by which ammonia passes from the bacteroid to the plant fraction of the nodule is of interest in understanding the Rhizobium/legume symbiosis. Free-living rhizobia induced to fix nitrogen in vitro also excrete ammonia into the environment (O'Gara \& Shanmugam, 1976; Tubb, 1976; Bergersen \& Turner, 1978).

Evidence for the existence of an ammonia carrier has been found in free-living Rhizobium leguminosarum (Glenn \& Dilworth, 1984; O'Hara et al., 1985) and in Rhizobium sp. 32H1 (Gober \& Kashket, 1983). However, the characteristics and regulation of the carriers appear to differ between the two species.

The few published reports suggest that bacteroids lack an ammonia carrier. Laane et al. (1980) reported that bacteroids of $R$. leguminosarum were unable to accumulate ammonia and excreted ammonia in response to a $\Delta \mathrm{pH}$ while Marsh et al. (1984) found reduced rates of ammonia uptake in bacteroids of Rhizobium sp. $32 \mathrm{Hl}$ compared to the free-living bacteria, and no uptake in Rhizobium japonicum bacteroids. Other free-living nitrogen-fixing bacteria, including Klebsiella pneumoniae (Kleiner, 1982), Clostridium pasteurianum (Kleiner \& Fitzke, 1981), Azotobacter vinelandii (Jayakumar \& Barnes, 1984) and Anabaena cylindrica (Rai et al., 1984), do have ammonia carriers and it seems that the membrane potential may be the driving force for ammonia transport by these carriers (Kleiner, 1981).

The ammonia analogue methylamine has been used to study ammonia uptake in many bacteria (Gober \& Kashket, 1983; Kleiner, 1982; Kleiner \& Fitzke, 1981; Jayakumar \& Barnes,

Abbreviations: CCCP, carbonyl cyanide $m$-chlorophenylhydrazone; DES, diethylstilboestrol. 
1984; Rai et al., 1984); in these bacteria, methylamine and ammonia share a common carrier. We have found this to be true for the slow-growing Rhizobium sp. ANU289 and have used methylamine to investigate ammonia uptake in both free-living bacteria and bacteroids. The present report shows that a specific ammonia carrier, probably energized by the membrane potential, is present in free-living bacteria but not in bacteroids.

\section{METHODS}

Bacterial strain. Rhizobium sp. ANU289 is a streptomycin resistant, non-mucoid derivative of strain CP283 (Mohapatra et al., 1983).

Media and growth conditions. For all experiments strain ANU289 was grown in medium N-FGM supplemented with 10 mm-glutamate as described previously (Howitt \& Gresshoff, 1985).

Nodulation and isolation of bacteroids. Bacteroids were isolated from nodules induced by strain ANU289 on siratro (Macroptilium atropurpureum). The growth of plants and bacteroid isolation procedure was described by Sandeman \& Gresshoff (1985).

Uptake experiments. Free-living strain ANU289 cells were harvested in mid-exponential phase, washed twice, and resuspended in $\mathrm{N}^{-} \mathrm{FGM}$ before being used for uptake experiments. Bacteroids were finally resuspended in a buffer containing $50 \mathrm{~mm}$-sucrose, $50 \mathrm{~mm}$-MOPS, $2 \mathrm{~mm}-\mathrm{MgCl}_{2}, 0 \cdot 1 \mathrm{~mm}$-dithiothreitol and $4 \%$ (w/v) polyvinylpyrrolidone. For experiments in which the $\mathrm{pH}$ dependence of methylamine uptake was investigated, $50 \mathrm{~mm}$-Tris was added to the buffers used for both bacteria and sacteroids to buffer at the higher $\mathrm{pH}$ range. Cells (bacteria or bacteroids) were pre-incubated at $30^{\circ} \mathrm{C} .\left[{ }^{14} \mathrm{C}\right]$ Methylamine $\left(10 \mu \mathrm{M}\right.$ unless otherwise stated; $56 \mathrm{mCi} \mathrm{mmol}^{-1}$, $2.07 \mathrm{GBq} \mathrm{mmol}^{-1}$ ) was added and, after I min, a sample was taken and the cells were collected by filtration. Cells were then washed three times in $\mathrm{N}^{-} \mathrm{FGM}$ containing $50 \mu \mathrm{M}$-methylamine. Radioactivity in the filters was measured by liquid scintillation counting after placing them in a scintillation vial with $10 \mathrm{ml}$ scintillation fluid (Permafluor/Triton X-100/toluene; $2: 25: 50$, by vol.).

Protein determinations These were made using a modified Lowry procedure (Schacterle \& Pollack, 1973).

\section{RESULTS AND DISCUSSION}

The uptake of $\left[{ }^{14} \mathrm{C}\right]$ methylamine was linear for at least $10 \mathrm{~min}$ in both bacteria and bacteroids (Fig. 1). Free-living bacteria had nearly 10 -fold higher transport activity than bacteroids. In free-living bacteria, methylamine uptake showed a distinct optimum at $\mathrm{pH} 7.0$ while in bacteroids, methylamine uptake increased exponentially with increasing $\mathrm{pH}$ (Fig. 2). The dependence of methylamine uptake on $\mathrm{pH}$ in bacteroids suggests that diffusion of uncharged methylamine was occurring. The $\mathrm{p} K_{\mathrm{a}}$ of methylamine is $10 \cdot 6$ and at the lower $\mathrm{pH}$ values shown in Fig. 2 very little methylamine will exist in the uncharged form. Consequently the uptake by bacteroids was much less than that by bacteria. However, as the $\mathrm{pH}$ increases more methylamine becomes uncharged and uptake by bacteroids becomes proportionally greater. The $\mathrm{pH}$ optimum observed in free-living bacteria indicates that a methylamine carrier is likely to be present.

Methylamine uptake in free-living bacteria showed Michaelis-Menten kinetics (apparent $K_{\mathrm{m}}$ $6.6 \mu \mathrm{M}$, Fig. 3). Uptake was competitively in hibited $\left(K_{\mathrm{i}} 0 \cdot 4 \mu \mathrm{M}\right)$ by $5 \mu \mathrm{M}$-ammonia. In bacteroids, methylamine uptake did not show saturation kinetics but increased linearly with increasing methylamine concentration up to $1 \mathrm{~mm}$ (Fig. 3). Uptake of methylamine by bacteroids was not affected by the presence of ammonia (results not shown).

Uptake in bacteria was inhibited by about $90 \%$ by 5 mm-azide (an electron transport inhibitor), and by $80 \%$ by $5 \mu \mathrm{g}$ valinomycin $\mathrm{ml}^{-1}$ (a potassium ionophore) suggesting that transport required energy. However, neither the ATPase inhibitor DES $(100 \mu \mathrm{M})$, nor the protonophore CCCP $(2 \mu \mathrm{M})$ inhibited uptake. Similar results were obtained in Klebsiella pneumoniae by Kleiner (1982), who argued that this would occur if methylamine uptake was energized by a membrane potential which was largely due to cations other than protons. CCCP would not dissipate this potential but, if $\mathrm{K}^{+}$contributed a large part of the membrane potential, valinomycin would. Rhizobium sp. ANU289 therefore seems to be similar to K. pneumoniae in this respect.

The glutamine synthetase/glutamate synthase pathway is the sole route of ammonia assimilation in strain ANU289 (Howitt \& Gresshoff, 1985). In an attempt to distinguish 


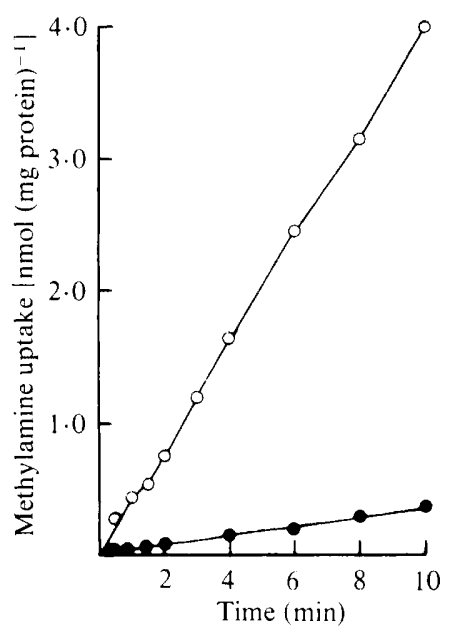

Fig. 1

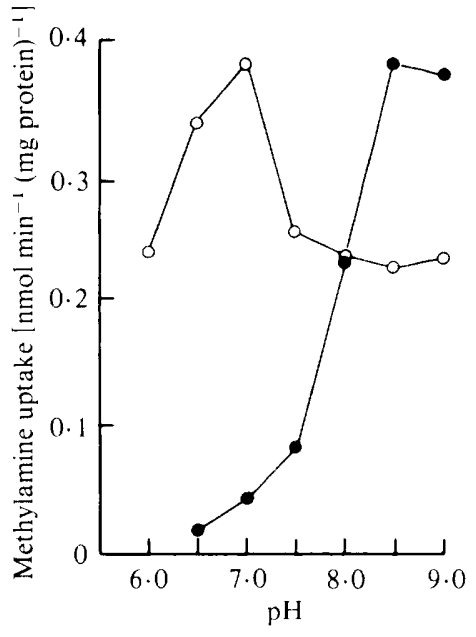

Fig. 2

Fig. 1. Time course of $\left[{ }^{1+C}\right]$ methylamine uptake by free-living bacteria $(O)$ and bacteroids $(O)$ Results for bacteria are the mean of three experiments (SE generally less than $10 \%$ ); results for bacteroids are from one typical experiment.

Fig. 2. $\mathrm{pH}$ dependence of $\left[{ }^{14} \mathrm{C}\right]$ methylamine uptake by free-living bacteria $(\mathrm{O})$ and bacteroids Results for bacteria are the average of three experiments (SE generally less than $10 \%$ ); results for bacteroids are from one typical experiment.
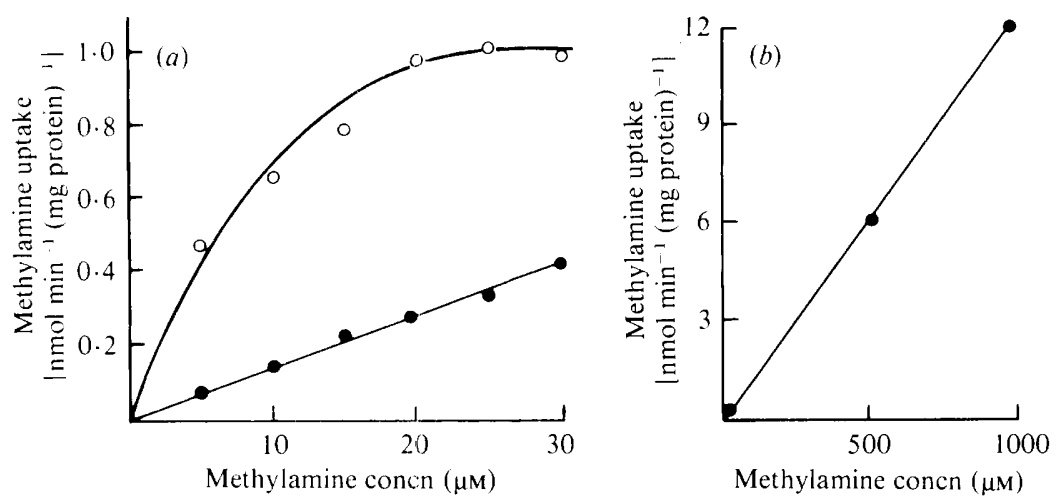

Fig. 3. (a) Concentration dependence of $\left[{ }^{1+} \mathrm{C}\right]$ methylamine uptake by free-living bacteria $(O)$ and bacteroids (O) up to $30 \mu \mathrm{M}$-methylamine. (b) Concentration dependence of $\left[{ }^{14} \mathrm{C}\right]$ methylamine uptake by bacteroids up to $1 \mathrm{mM}$-methylamine. Results for bacteria are the average of three experiments ( $\mathrm{SE}$ generally less than $10 \%$ ); results for bacteroids are from one typical experiment.

between uptake of methylamine and its metabolism, we examined the effect of the glutamine synthetase inhibitor methionine sulphoximine on methylamine uptake. Methionine sulphoximine $(5 \mathrm{mM})$, which completely inhibited both the glutamine synthetases that are present in strain ANU289, inhibited methylamine uptake by about $30 \%$ (results not shown). This suggests that some methylamine is converted to $\gamma$-N-methylglutamine, as it is in Rhizobium sp. $32 \mathrm{Hl}$ (Gober \& Kashket, 1983). However, most of the uptake observed was independent of metabolism. The fact that methylamine uptake was inhibited by valinomycin and azide confirms that methylamine uptake, and not metabolism was occurring.

When $10 \mathrm{~mm}-\mathrm{NH}_{4} \mathrm{Cl}$ was added to a nitrogen starved strain ANU289 culture, $90 \%$ of the methylamine uptake activity was lost after $24 \mathrm{~h}$ (Fig. 4). Resuspension of these cells in a medium 


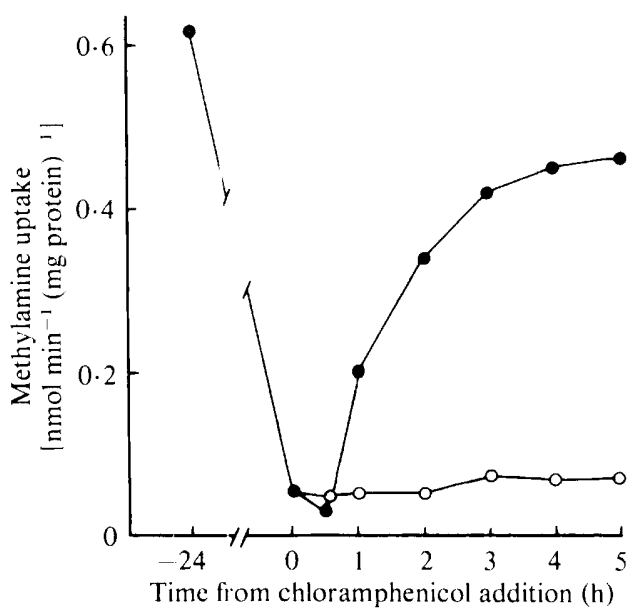

Fig. 4. Recovery of methylamine uptake after repression by ammonia. $\mathrm{NH}_{4} \mathrm{Cl}(10 \mathrm{~mm})$ was added to a mid-exponential phase culture, which was then allowed to grow for a further $24 \mathrm{~h}$. The cells were then washed and resuspended in N-FGM plus $10 \mathrm{mM}$-glutamate with (O) and without (O) $0.2 \mathrm{mg}$ chloramphenicol $\mathrm{ml}^{-1}$. Samples were taken and $\left[{ }^{14} \mathrm{C}\right]$ methylamine uptake activity was determined at the times indicated.

containing $10 \mathrm{~mm}$-glutamate, but no $\mathrm{NH}_{4} \mathrm{Cl}$, resulted in the recovery of two-thirds of the initial activity within $5 \mathrm{~h}$ (Fig. 4). The recovery of methylamine uptake activity was completely inhibited by chloramphenicol (Fig. 4). The carrier thus appears to be regulated at a genetic level, with ammonia repressing the synthesis of the carrier and nitrogen starvation derepressing it. Regulation of the ammonia carrier of $R$. leguminosarum (O'Hara et al., 1985) and of $K$. pneumoniae (Kleiner, 1982) occurs in a similar manner and appears to be part of the general nitrogen control system in the latter species. This contrasts with the case of $A$. vinelandii where, in the presence of excess ammonia, a build up of metabolites inhibitory to ammonia uptake occurs (Jayakumar \& Barnes, 1984).

The ammonia carrier in bacteroids of strain ANU289 and other Rhizobium spp. (Laane et al., 1980; Marsh et al., 1984; O'Hara et al., 1985) may be absent because the ammonia produced by $\mathrm{N}_{2}$ fixation represses the carrier, as it does in the free-living state. $\mathrm{O}_{2}$ has also been implicated in the regulation of the ammonia carriers of other Rhizobium spp. but different reports are contradictory. Marsh et al. (1984) found that low $\mathrm{O}_{2}$ tension repressed the ammonia carrier of both the cowpea strain $32 \mathrm{H} 1$ and $R$. japonicum. However, Gober \& Kashket (1983), also working with $32 \mathrm{Hl}$, suggested that the carrier would be induced in the bacteroid by low $\mathrm{O}_{2}$ and would function to actively export ammonia to the plant cytosol. Our results show that this latter explanation definitely does not hold for strain ANU289 bacteroids.

S.M.H. is the recipient of an Australian Government Postgraduate Research Award. Agrigenetics Research Associates supported parts of this study.

\section{REFERENCES}

Bergersen, F. J. \& Turner, G. L. (1978). Activity of nitrogenase and glutamine synthetase in relation to availability of oxygen in continuous cultures of cowpea Rhizobium sp. supplied with excess ammonium. Biochimica et biophysica acta 538, 406-416.

Dilworth, M. J. \& GlenN, A. R. (1982). Movements of ammonia in Rhizobium leguminosarum. Journal of General Microbiology 128, 29-37.
GlenN, A. R. \& Dilworth, M. J. (1984). Methylamine and ammonium transport systems in Rhizobium leguminosarum MNF3841. Journal of General Microbiology 130, 1961-1968.

Gober, J. W. \& Kashket, E. R. (1983). Methylammonium uptake by Rhizobium sp. 32H1. Journal of Bacteriology 153, 1196-1201.

HowitT, S. M. \& Gresshoff, P. M. (1985). Ammonia 
regulation of glutamine synthetase in Rhizobium $\mathrm{sp.}$ ANU289. Journal of General Microbiology 131, 14331440.

JAYAKUMAR, A. \& BARNES, E. M. (1984). The role of glutamine in regulation of ammonium transport in Azotobacter vinelandii. Archives of Biochemistry and Biophysics 231, 95-101.

KLEINER, D. (1981). The transport of $\mathrm{NH}_{3}$ and $\mathrm{NH}_{4}^{+}$ across biological membranes. Biochimica et biophysica acta 639, 41-52.

KLEINER, D. (1982). Ammonium (methylammonium) transport by Klebsiella pneumoniae. Biochimica et biophysica acta $\mathbf{6 8 8}, 702-708$.

KLEINER, D. \& FITZKE, E. (1981). Some properties of a new electrogenic transport system: the ammonium (methylammonium) carrier from Clostridium pasteurianum. Biochimica et biophysica acta 641, 138147.

Laane, C., Krone, W., Konings, W. \& Veeger, C. (1980). Short term effect of ammonium chloride on nitrogen fixation by Azotobacter vinelandii and by bacteroids of Rhizobium leguminosarum. European Journal of Biochemistry 103, 39-46.

MARSh, S. D., WyZA, R. E. \& Evans, W. R. (1984). Uptake of ammonia and methylamine by free-living and symbiotic Rhizobium. Plant Physiology 75S, abst. 155 , p. 28.
Mohapatra, S. S., Bender, G. L., Shine, J., Rolfe, B. G. \& GresshofF, P. M. (1983). In vitro expression of nitrogenase activity in Parasponia Rhizobium strain ANU289. Archives of Microbiology 134, 12-16.

O'Gara, F. \& Shanmugam, K. T. (1976). Regulation of nitrogen fixation by rhizobia. Biochimica et biophysica acta 437, 313-321.

O'Hara, G. W., Riley, I. T., Glenn, A. R. \& DILWORTH, M. J. (1985). The ammonium permease of Rhizobium leguminosarum MN3841. Journal of General Microbiology 131, 757-764.

RaI, A. N., Rowell, P. \& Stewart, W. D. P. (1984). Evidence for an ammonium transport system in freeliving and symbiotic cyanobacteria. Archives of Microbiology 137, 241-246.

Sandeman, R. A. \& GresshofF, P. M. (1985). Nitrogenase activity and inactivation in isolated bacteroids from the legume siratro and the nonlegume Parasponia rigida. Plant Science Letters 37, 199-204.

Schacterle, G. R. \& Pollack, R. L. (1973). Simplified method for quantitative assay of small amounts of protein in biological material. Analytical Biochemistry 51, 654-655.

TuBB, R. S. (1976). Regulation of nitrogen fixation in Rhizobium spp. Applied and Environmental Microbiology 32, 483-488. 